\title{
Characterisation of the biological effects of neurohypophysial peptides on seminiferous tubules
}

\section{G C Harris and H D Nicholson}

Department of Anatomy, School of Medical Sciences, University of Bristol, Bristol BS8 1TD, UK

(Requests for offprints should be addressed to G C Harris, Department of Anatomy, School of Medical Sciences, University of Bristol, University Walk, Bristol BS8 1TD, UK)

\begin{abstract}
Oxytocin (OT) is present in the mammalian testis and has been postulated to play a role in modulation of seminiferous tubule contractility. However, recent evidence suggests that the myoid cells responsible for such contractile activity do not express OT receptors. In this study computer-assisted analysis and time-lapse videomicrography were used to investigate the biological effects of neurohypophysial peptides and their analogues on seminiferous tubule contractility. Adult rat testes were placed in fresh oxygenated Dulbecco's modified Eagle's medium (DMEM) F12 medium, decapsulated and the tubules gently teased apart. A small section of tubule was placed in a microslide chamber and perifused with medium. Seminiferous tubules were treated with OT $(2 \mathrm{nM}),\left[\operatorname{Arg}^{8}\right]-$ vasopressin (AVP, $0 \cdot 2 \mathrm{nM})$ or $\left[\mathrm{Thr}^{4}, \mathrm{Gly}^{7}\right]$-OT (TGOT, $2 \mathrm{nM}, 8 \mathrm{nM}$ and $0 \cdot 2 \mu \mathrm{M}$ ). Specific antagonists were also given simultaneously with OT and AVP treatments. Data were analysed to give arbitrary units of contractility.

Both OT and AVP increased tubule contractility, with AVP being at least 10 times more potent than OT. Treatment with the selective OT antagonist, desGly-
\end{abstract}

$\mathrm{NH}_{2}, \mathrm{~d}\left(\mathrm{CH}_{2}\right)_{5}\left[\mathrm{~d}-\mathrm{Tyr}^{2}, \mathrm{Thr}^{4}\right]$-ornithine vasotocin (OTA, $0 \cdot 2 \mu \mathrm{M}$ and $2 \mu \mathrm{M})$ significantly reduced OT-induced increases in seminiferous tubule contractility but had no effect on AVP-induced responses. In contrast, the AVP antagonist, Phaa-d-Tyr(Me)-Phe-Gln-Asn-Arg-ProArg-Tyr- $\mathrm{NH}_{2}$ (AVPA) was more potent at reducing AVP-induced increases than OT-induced responses. The selective non-peptide AVPA SR 49059 blocked the response to both peptides in a similar manner, whilst the non-peptide OTA L367,773 did not block OT-induced increases in seminiferous tubule contractility at doses that were slightly inhibitory to AVP-induced responses. The specific OT agonist TGOT did not induce a contractile response. The data in this study demonstrate that in the testis AVP acts via $V_{1 a}$ receptors to stimulate contractile activity and suggest that OT may act via a receptor which differs from the classical $V_{1 a}$ and uterine-type OT receptor. These findings support a role for OT in the regulation of seminiferous tubule contractility and raise the possibility that AVP may also be important in this process.

Journal of Endocrinology (1998) 156, 35-42

\section{Introduction}

The peptide oxytocin (OT) is present in the testis of a number of species (Nicholson et al. 1984), and in the rat local synthesis by Leydig cells has been demonstrated (Guldenaar \& Pickering 1985, Nicholson \& Hardy 1992). The hormone has been shown to increase contractility of seminiferous tubules in vitro (Niemi \& Kormano 1965) in a dose-dependent manner (Worley et al. 1988) and such movements have been hypothesised to aid in both spermiation and sperm transport (Gravis 1980, Worley et al. 1984). Selective removal of Leydig cells with the drug ethane dimethane sulphonate reduces testicular OT and decreases seminiferous contractility in vitro, yet normal contractility can be restored by treatment with OT (Nicholson et al. 1987). In addition, treatment of hypogonadal mice with either luteinising hormone or testosterone results in the development of tubule contractility and the appearance of testicular OT (Nicholson et al. 1986), suggesting a physiological role for OT in the regulation of tubule contractility.

However, recent studies have suggested that testicular myoid cells do not express the OT receptor, essential for OT to have such a role in tubule contractility. In cultures of purified peritubular myoid cells, $\left[\operatorname{Arg}^{8}\right]$-vasopressin (AVP), but not the selective OT agonist $\left[\mathrm{Thr}^{4}, \mathrm{Gly}^{7}\right]-\mathrm{OT}$ (TGOT) stimulates the accumulation of inositol phosphate, which is produced upon the activation of the $\mathrm{V}_{1}$ and OT receptor (Howl et al. 1995). Similarly, the specific OT receptor agonist $\left[\mathrm{Gly}^{7}\right]$-OT does not stimulate contractions of seminiferous tubules in vitro (Pickering et al. 1989). Furthermore, autoradiographical localisation of AVP receptors has been achieved in interstitial tissue and seminiferous tubule epithelial surfaces (Phillips et al. 1989), whereas the localisation of OT receptors is limited to the Leydig cells (Bathgate \& Sernia 1994). Howl et al. (1995) 
Table 1 Summary of the antagonists used to block OT- and AVP-induced contractile responses of seminiferous tubules in vitro. ${ }^{\mathrm{a}}$ In vitro $\mathrm{pA}_{2}$ values represent the negative logarithm of the molar concentration of antagonist $\left(\mathrm{A}_{2}\right)$ which reduces the response to $2 \times$ units of agonist to equal the response to $1 \times$ unit of agonist in the absence of antagonist.

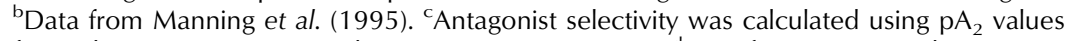
for rat liver $V_{1 \text { a }}$ receptors and rat uterine OT receptors. ${ }^{d}$ Data from Evans et al. (1993). ${ }^{\mathrm{e} C}$ Calculated using $\mathrm{IC}_{50}$ values for rat liver $\mathrm{V}_{1 \mathrm{a}}$ receptors and rat uterus OT receptors (Evans et al. 1993). 'Data from Schmidt et al. (1991). ${ }^{g}$ Calculated using $K_{i}$ values for rat liver $V_{1 a}$ receptors and rat uterus OT receptors (Schmidt et al. 1991). ' Data from Serradeil-Le Gal et al. (1993). 'Calculated using $K_{i}$ values for rat liver $V_{1 a}$ receptors and rat mammary gland OT receptors (Serradeil-Le Gal et al. 1993)

\begin{tabular}{|c|c|c|c|c|}
\hline \multirow[b]{3}{*}{$\begin{array}{l}\text { Antagonist } \\
\text { desGly- } \mathrm{NH}_{2}, \mathrm{~d}\left(\mathrm{CH}_{2}\right)_{5}[\mathrm{D}- \\
\left.\mathrm{Tyr}^{2}, \mathrm{Thr}^{4}\right] \text {-OVT }\end{array}$} & \multirow[b]{2}{*}{ Type } & \multicolumn{2}{|l|}{$\mathrm{pA}_{2}{ }^{\mathrm{a}}$} & \multirow{2}{*}{$\begin{array}{l}\text { Selectivit) } \\
\text { (OT/AVP) }\end{array}$} \\
\hline & & OT & AVP & \\
\hline & Peptide OT & $7 \cdot 37^{\mathrm{b}}$ & $5 \cdot 39^{b}$ & $95^{c}$ \\
\hline $\mathrm{L} 367,773$ & Non-peptide OT & $7 \cdot 93^{d}$ & - & $108^{\mathrm{e}}$ \\
\hline $\begin{array}{l}\text { Phaa-D-Tyr(Me)-Phe-Gln- } \\
\text { Asn-Arg-Pro-Arg-Tyr-NH }{ }_{2}\end{array}$ & Peptide AVP & - & $8 \cdot 94^{f}$ & $0 \cdot 13^{\mathrm{g}}$ \\
\hline SR 49059 & Non-peptide AVP & - & $9 \cdot 42^{h}$ & $0.002^{i}$ \\
\hline
\end{tabular}

therefore hypothesised that OT stimulates seminiferous tubule contractility by activation of the $\mathrm{V}_{1 \mathrm{a}}$ receptors on myoid cells.

The aim of this study was to observe the effects of selective $\mathrm{V}_{1 \mathrm{a}}$ and $\mathrm{OT}$ receptor antagonists on OT- and AVP-induced contractility in seminiferous tubules in vitro and establish whether OT acts via $\mathrm{V}_{1 \mathrm{a}}$ receptors.

\section{Materials and Methods}

\section{Preparation of seminiferous tubules}

Adult male Sprague-Dawley rats were killed by cervical dislocation. A testis was removed, decapsulated and the seminiferous tubules gently teased apart whilst submerged in pre-oxygenated Dulbecco's modified Eagle's medium (DMEM F12; GIBCO Ltd, Paisley, Strathclyde, UK) supplemented with penicillin and streptomycin $(50 \mathrm{U} / \mathrm{ml}$ and $50 \mu \mathrm{g} / \mathrm{ml}$ respectively, Sigma Chemical Company, Poole, Dorset, UK) at $34^{\circ} \mathrm{C}$. Stage VII-VIII of the spermatogenic cycle was identified by transillumination as described by Parvinen \& Ruokonen (1982) to avoid the variation in basal contractility that occurs at different stages of the spermatogenic cycle (Harris \& Nicholson 1995). Approximately $10 \mathrm{~mm}$ stage VII-VIII tubule were excised and drawn into a microslide chamber and then perifused with fresh DMEM F12 medium (with antibiotics) at $1.25 \mathrm{ml} / \mathrm{h}$ using a peristaltic pump. The tubule was allowed to become established for $3 \mathrm{~h}$ in control medium before administration of peptide(s) for $1 \mathrm{~h}$, followed by perifusion for a further hour with control medium. The experiment was repeated using tubules from different animals.

Experiments were also performed where the same seminiferous tubule was given more than one treatment.
Tubules were allowed $30 \mathrm{~min}$ to become established in medium, before administration of peptide for $30 \mathrm{~min}$, followed by a $45 \mathrm{~min}$ period of perifusion with control medium. Treatment was repeated two further times with the same dose of peptide, but with the addition of antagonist. The dose of antagonist used was increased by an order of magnitude between the second and third treatment.

\section{The perifusion chamber}

A microslide (Camlab Ltd, Cambridge, Cambs, UK) with an inner path length of $400 \mu \mathrm{m}$ was used for containment of the seminiferous tubule and was connected to silicone tubing (Anachem, Luton, UK). The entire apparatus was enclosed in a cabinet held at $34^{\circ} \mathrm{C}$ and suspended on an anti-vibration table (U-frame Isolator, Ealing, UK).

\section{Peptides}

Ligands used in this study were: TGOT ([4-threonine,7glycine]-oxytocin, Peninsula Laboratories Inc., CA, USA); OT (Cambridge Research Biochemicals, Cambridge, Cambs, UK) and AVP (UCB Bioproducts, Brussels, Belgium). Antagonists were kindly donated by $\mathrm{M}$ Manning (Toledo, Ohio, USA) and C Serradeil-Le Gal and coworkers, Toulouse, France. A list of the antagonists used is shown in Table 1. The concentrations of antagonists were selected so that they were similar to their $A_{2}$ values; where the $\mathrm{pA}_{2}$ value represents the negative logarithm of the molar concentration of antagonist $\left(\mathrm{A}_{2}\right)$ which reduces the response to $2 \times$ units of agonist to equal the response to $1 \times$ unit of agonist in the absence of antagonist. All peptides were first dissolved in distilled 
water and then diluted in culture medium to the appropriate concentrations used in the perifusion chamber. Non-peptide antagonists were first dissolved in dimethylsulphoxide (DMSO) before being subsequently diluted in culture medium. The concentrations of DMSO used in this study had no effect on OT- or AVP-induced responses of seminiferous tubule contractility, although higher doses of DMSO (>2\%) were inhibitory (data not shown).

\section{Data analysis}

Seminiferous tubule contractility was monitored as previously described by Worley \& Leendertz (1988). Briefly, $\times 12$ time-lapse videomicrographic recordings were performed on tubules in vitro. Movement was quantified using an electronic bar, superimposed on a vertically positioned tubule, which measured the changes in contrast which occurred on a video screen when the tubule moved laterally. These changes in contrast were converted to voltages and recorded by a computer. The amplitude and duration of contractions were used to give arbitrary units (a.u.) of contractile activity such that 10 a.u. represented a 10-fold increase in activity compared with 1 a.u.

Linear interpolation was used to measure the response to various chemical treatment paradigms to account for any shift in the baseline of tubule contractility during the experiment. Linear interpolation of contractility using $2 \mathrm{~h}$ of control data to interpolate an estimate for the control hour was first performed to test if this technique was feasible.

Responses to peptides were expressed as both the ratio and difference between the 'actual contractility during treatment (a.u.)' compared with the 'linearly interpolated contractility during treatment (a.u.)'. Data were expressed in both ways to allow for slight variation in basal contractility (data not shown) that occurred between groups (ANOVA, $P<0 \cdot 05$ ), although no significant variation in basal contractility occurred within OT \pm antagonist/ agonist treated groups or within AVP \pm antagonist/agonist treated groups (ANOVA). Data were expressed as means \pm s.E.M. Student's paired $t$-tests were performed to test for significant increases in contractility. The effects of antagonists on contractile response to OT and AVP were analysed by ANOVA and Student's $t$-tests. Representative contractility traces of the effects of selective peptide and non-peptide antagonists on OT- and AVP-induced responses in seminiferous tubule contractility are also provided.

\section{Results}

\section{Effects of OT, AVP and TGOT on seminiferous tubule contractility}

Representative traces showing the effects of treatment with OT $(8 \mathrm{nM})$ and AVP $(0 \cdot 2 \mathrm{nM})$ on seminiferous tubule a
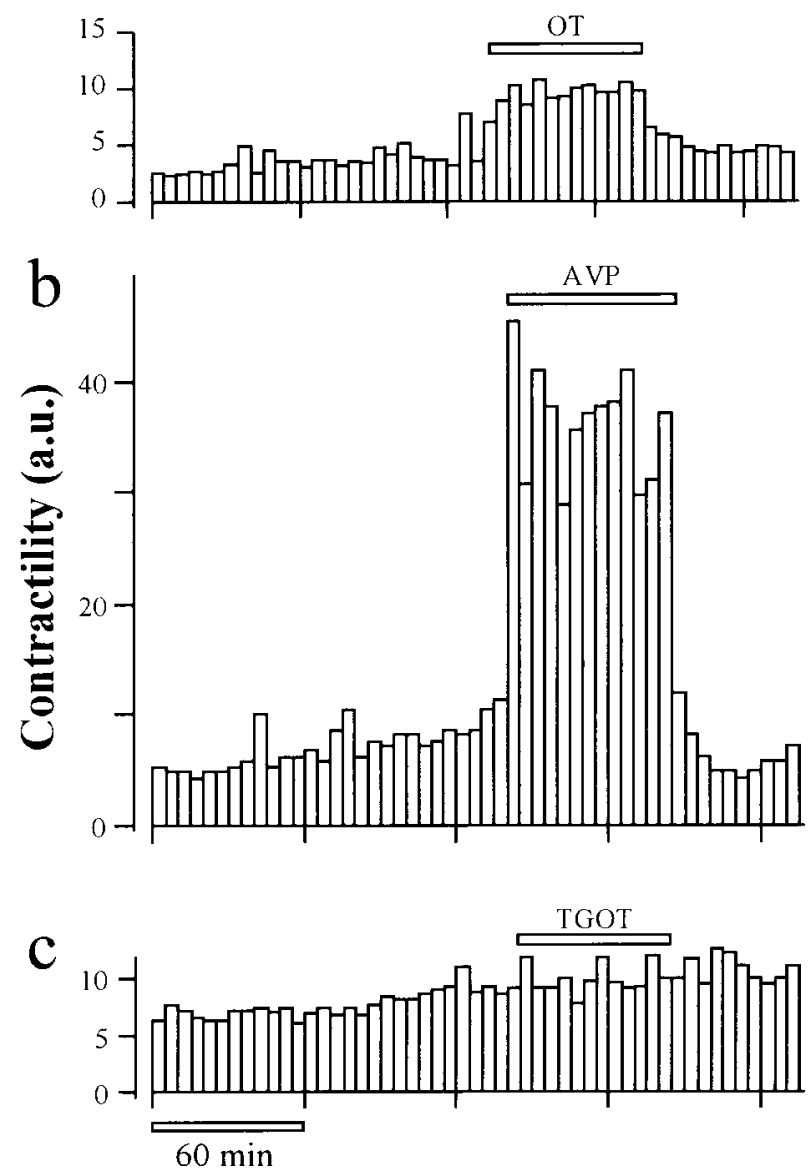

Figure 1 Representative contractility recordings of individual seminiferous tubules and their response to (a) OT (8 nM), (b) AVP $(0 \cdot 2 \mathrm{nM})$ and (c) TGOT (2 nM). Each bar represents the mean contractility of the tubule over a 5-min period.

contractility are shown in Fig. $1 \mathrm{a}$ and $\mathrm{b}$ respectively. Both OT and AVP increased contractile activity with AVP being the more potent peptide. The increase in contractility persisted in the presence of the peptides, returning to basal levels when the peptide-containing medium was replaced with control medium. TGOT treatment (2 nM) did not produce any alterations in contractile activity (Fig. 1c). Figure 2 shows the mean values of experiments from different animals analysed using linear interpolation. Treatment with both OT $(2 \mathrm{nM})$ and AVP $(0 \cdot 2 \mathrm{nM})$ produced significant increases in contractility. AVP was eight times more potent at stimulating seminiferous tubule contractility at a concentration an order of magnitude less than OT, when expressed as the increase in contractility (Fig. 2a), or 6.2 times more potent when expressed as the relative contractile response (Fig. $2 b$ ). TGOT treatment did not lead to significant differences in contractility even at concentrations as high as $0 \cdot 2 \mu \mathrm{M}$. 


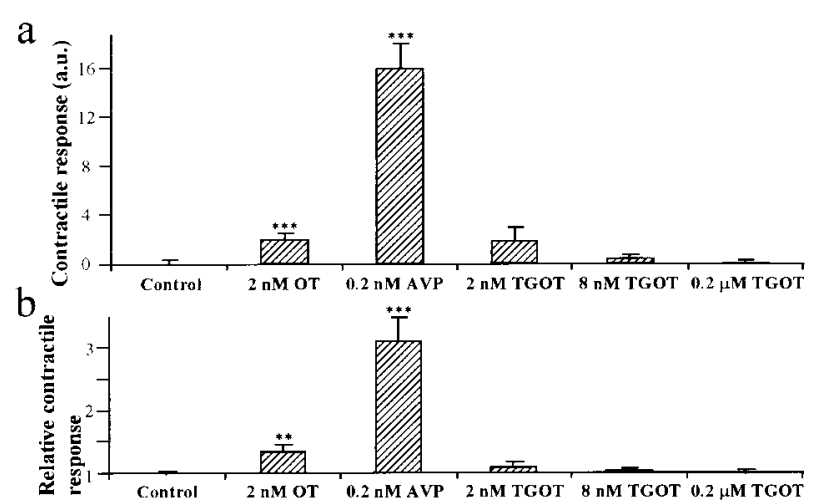

Figure 2 The effects of treatment with OT, AVP and TGOT for $1 \mathrm{~h}$ on seminiferous tubule contractility. Data were analysed by linear interpolation. Control period $(n=12)$, OT ( $2 \mathrm{nM}, n=15)$, AVP $(0 \cdot 2 \mathrm{nM}, n=6)$ and TGOT $(2 \mathrm{nM}, n=7 ; 8 \mathrm{nM}, n=2$ and $0 \cdot 2 \mu \mathrm{M}$, $n=2$ ). Responses are represented as (a) differences in contractility and (b) relative contractility compared with the control period. Data are expressed as means \pm S.E.M. ${ }^{*} P<0 \cdot 01,{ }^{*} * *<0 \cdot 001$ vs linearly interpolated control.

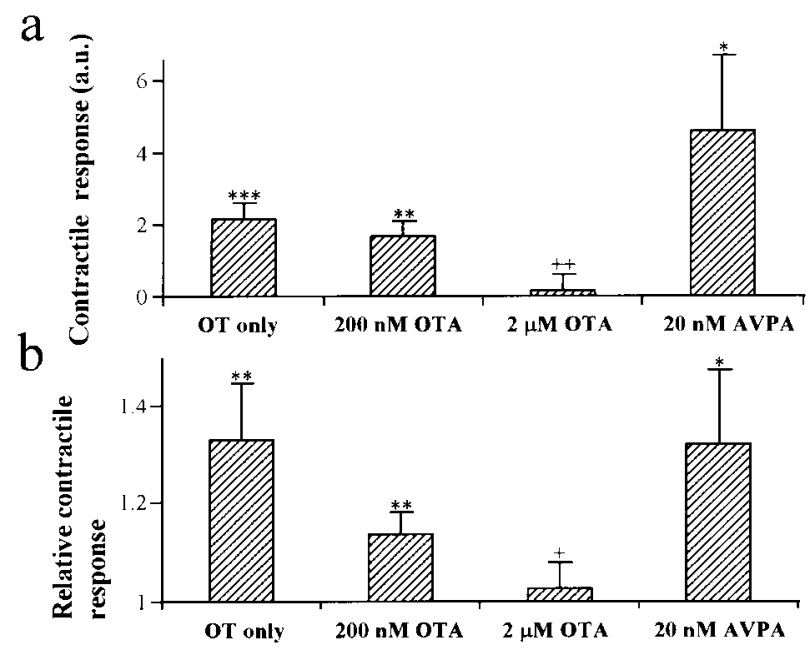

Figure 3 The effects of desGly- $\mathrm{NH}_{2}, \mathrm{~d}\left(\mathrm{CH}_{2}\right)_{5}\left[\mathrm{~d}-\mathrm{Tyr}^{2}, \mathrm{Thr}^{4}\right]$-OVT and

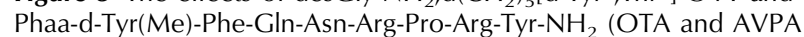
respectively) on OT-induced $(2 \mathrm{nM})$ increases in seminiferous tubule contractility. Responses are represented as (a) differences in contractility and (b) relative contractility compared with the control period. Data are expressed as means \pm S.E.M. (OT alone, $n=15$; OT+200 nM OTA, $n=6$; OT $+2 \mu$ M OTA, $n=6$ and OT $+20 \mathrm{nM}$ AVPA, $n=5) .{ }^{*} P<0 \cdot 05,{ }^{*} P<0 \cdot 01,{ }^{* * *} P<0 \cdot 001$ vs linearly interpolated control. ${ }^{+} P<0 \cdot 05,{ }^{++} P<0 \cdot 01$ vs the effects of OT alone.

Effects of antagonists on OT- and AVP-induced increases in seminiferous tubule contractility

Treatment with the OT antagonist desGly$\mathrm{NH}_{2}, \mathrm{~d}\left(\mathrm{CH}_{2}\right)_{5}\left[\mathrm{~d}-\mathrm{Tyr}^{2}, \mathrm{Thr}^{4}\right]$-ornithine vasotocin $(\mathrm{OVT})$ (OTA) significantly reduced OT-induced increases in seminiferous tubule contractility in a dose-dependent manner (Fig. 3a and b, ANOVA, $P<0 \cdot 05$ ). Treatment with $2 \mu \mathrm{M}$ of this selective OTA significantly inhibited

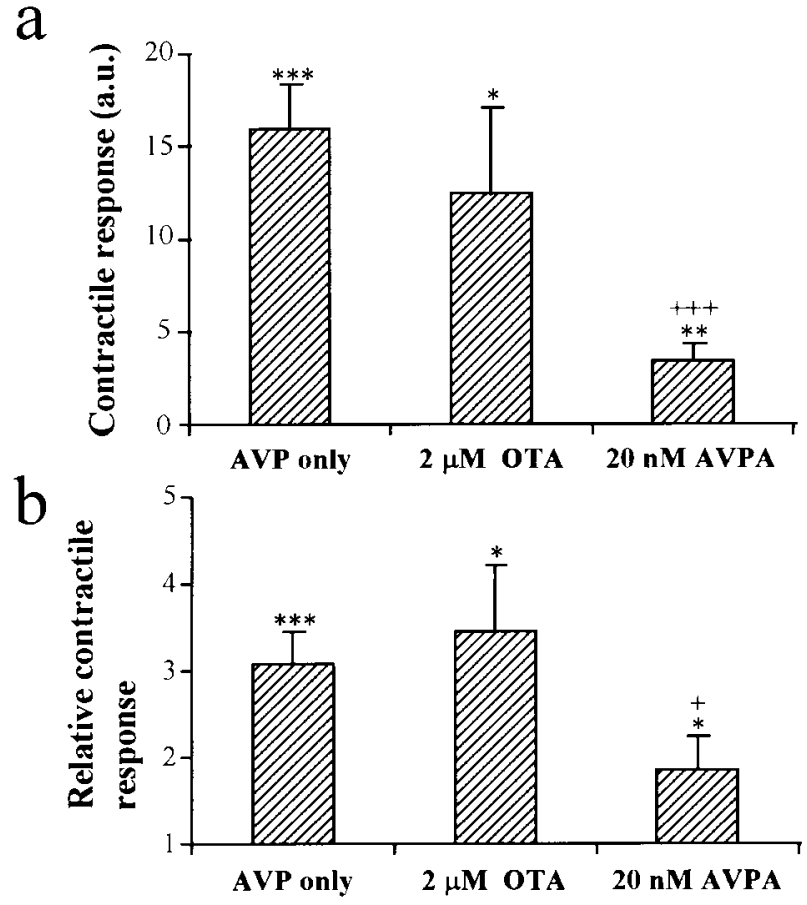

Figure 4 The effects of desGly- $\mathrm{NH}_{2}, \mathrm{~d}\left(\mathrm{CH}_{2}\right)_{5}\left[\mathrm{~d}-\mathrm{Tyr}^{2}, \mathrm{Thr}^{4}\right]$-OVT and Phaa-d-Tyr(Me)-Phe-Gln-Asn-Arg-Pro-Arg-Tyr-NH ${ }_{2}$ (OTA and AVPA respectively) on AVP-induced $(0 \cdot 2 \mathrm{nM})$ increases in seminiferous tubule contractility. Responses are represented as (a) differences in contractility and (b) relative contractility compared with the control period. Data are expressed as means \pm S.E.M. $(n=6)$. ${ }^{*} P<0 \cdot 05$, ${ }^{* *} P<0 \cdot 01,{ }^{* * *} P<0 \cdot 001$ vs linearly interpolated control. ${ }^{+} P<0 \cdot 05$, ${ }^{+++} P<0.001$ vs the effects of AVP alone.

the contractile response to OT such that no significant change from basal contractility occurred. Treatment with the AVP antagonist, Phaa-d-Tyr(Me)-Phe-Gln-Asn-ArgPro-Arg-Tyr- $\mathrm{NH}_{2}$ (AVPA, $20 \mathrm{nM}$ ) had no significant effect on OT-induced increases in contractility.

In contrast, $2 \mu \mathrm{M}$ OTA had no significant effect on AVP-induced increases in contractility when expressed as both the difference in contractility and relative contractile response (Fig. 4a and $\mathrm{b}$ respectively). However, the AVP-stimulated increases in contractility were reduced by treatment with the AVPA $(20 \mathrm{nM})$, expressed as either the difference in contractility $(P<0 \cdot 01)$ or relative contractility $(P<0 \cdot 05)$ compared with AVP-induced contractility in the absence of antagonist.

In order to further characterise the effects of OT and AVP on tubule contractility the effects of other non-peptide antagonists were compared. Consecutive treatments were given to the same seminiferous tubule.

The effects of increasing doses of OTA and AVPA on OT- and AVP-induced increases in seminiferous tubule contractility in individual tubules gave similar results as above (Figs 5 and 6 respectively), showing that the effects of the peptides are not reduced following 


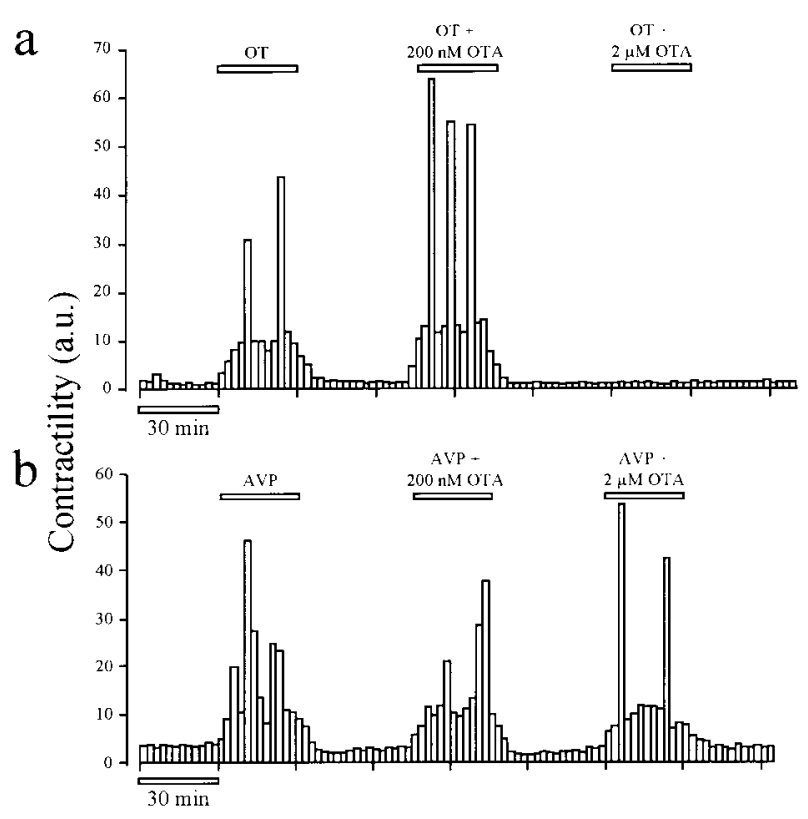

Figure 5 Representative contractility recordings of seminiferous tubules from adult rats showing the effects of two periods of treatment with the OT antagonist desGly- $\mathrm{NH}_{2}, \mathrm{~d}\left(\mathrm{CH}_{2}\right)_{5}$ [d-Tyr ${ }^{2}$, Thr $^{4}$ ]-OVT (OTA, $200 \mathrm{nM}$ and $2 \mu \mathrm{M}$ ) on (a) OT- $(20 \mathrm{nM})$ and (b) AVP- $(0 \cdot 2 \mathrm{nM})$ induced increases in seminiferous tubule contractility. Each bar represents the mean contractility of the tubule over a $2 \cdot 5$-min period.

repeated treatments to individual tubules. The data also show that although AVPA does not reduce OT-induced responses at $20 \mathrm{nM}$, it does antagonise the response at the higher dose of $200 \mathrm{nM}$ (Fig. 6a).

Representative traces $(n=3)$ of the effects of the nonpeptide antagonists SR 49059 and L367,773 on OT- and AVP-induced increases are shown in Figs 7 and 8 respectively. The selective $\mathrm{V}_{1}$ antagonist SR 49059 decreased both OT- and AVP-induced increases in seminiferous tubule contractility in a similar manner in all of the tubules studied (Fig. 7a and b respectively). The OTA L367,773 did not affect OT-induced contractile responses (Fig. 8a) at doses of up to $2 \mu \mathrm{M}$, however a slight decrease in the AVP-induced increases in seminiferous tubule contractility was observed in all of the tubules.

\section{Effects of TGOT on OT- and AVP-induced increases in seminiferous tubule contractility}

TGOT is known to be a highly selective agonist for the OT receptor. To further investigate its lack of effect on basal contractile activity, the effects of the peptide on OT- and AVP-induced contractility were examined.

TGOT did not affect OT-induced increases in contractility (Fig. 9a and b). TGOT $(0 \cdot 2 \mu \mathrm{M})$ significantly reduced AVP-induced increases in contractility when expressed as the difference in contractility, but had no

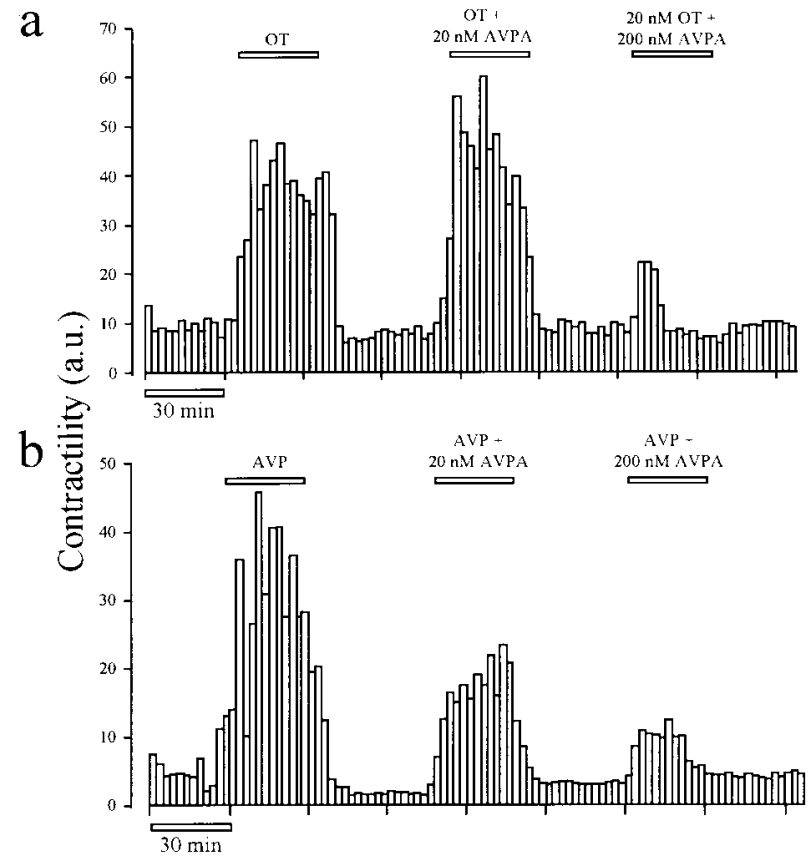

Figure 6 Representative contractility recordings of seminiferous tubules from adult rats showing the effects of two periods of treatment with the AVP antagonist, Phaa-d-Tyr(Me)-

Phe-Gln-Asn-Arg-Pro-Arg-Tyr- $\mathrm{NH}_{2}$ (AVPA, $20 \mathrm{nM}$ and $200 \mathrm{nM}$ ) on (a) OT- $(20 \mathrm{nM})$ and (b) AVP- $(0 \cdot 2 \mathrm{nM})$ induced increases in seminiferous tubule contractility. Each bar represents the mean contractility of the tubule over a $2 \cdot 5$-min period.

significant effect when expressed as the relative contractile response (Fig. 10a and $\mathrm{b}$ respectively). There was no significant effect of $20 \mathrm{nM}$ TGOT on AVP-induced increases in contractility.

\section{Discussion}

This study demonstrates that OT and AVP can both stimulate seminiferous tubule contractility in vitro at concentrations similar to those found in the testis (Pickering et al. 1989). Furthermore, these data show that, in vitro, AVP is more potent than OT at stimulating contractility. Both neurohypophysial hormones are present in the mammalian testis (Pickering et al. 1990). OT is synthesised by Leydig cells within the testis and concentrations of the peptide are regulated not only by gonadal hormones (Nicholson \& Hardy 1992), but also by the seminiferous epithelium. OT secretion is increased by factors secreted by the Sertoli cells (Pickering et al. 1989) and appears to be modulated by the presence of specific germ cells within the seminiferous epithelium (Nicholson et al. 1994). OT has been shown to both regulate seminiferous tubule contractility in vitro (Worley et al. 1984) and alter sperm transport in vivo (Voglmayr 1975, Frayne et al. 1996), 


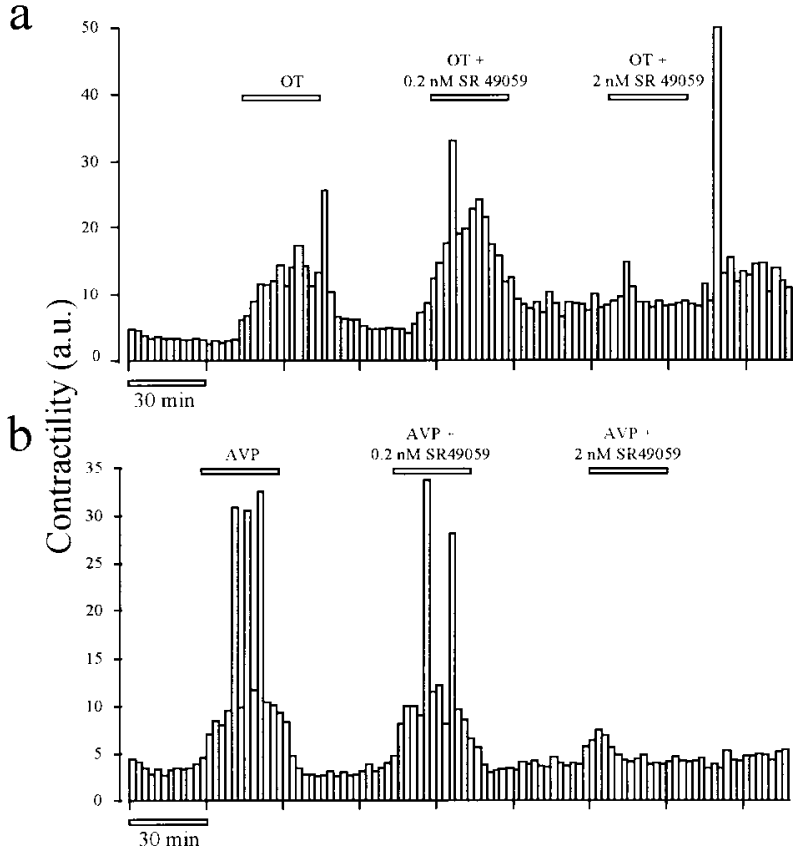

Figure 7 Representative contractility recordings of seminiferous tubules from adult rats showing the effects of the AVP antagonist SR $49059(0 \cdot 2$ and $2 \mathrm{nM})$ on (a) OT- (20 nM) and (b) AVP$(0 \cdot 2 \mathrm{nM})$ induced increases in seminiferous tubule contractility. Each bar represents the mean contractility of the tubule over a $2 \cdot 5$-min period.

suggesting that the peptide may have a physiological role in fertility. AVP has been implicated as a local regulator of testosterone secretion within the testis (Adashi et al. 1984) but until now its stimulatory effects on seminiferous tubule contractility have not been recognised. The AVP gene is expressed in the rat testis (Foo et al. 1991) and local synthesis has been demonstrated (Ivell et al. 1992). However, whilst immunoreactive AVP has been identified within the rat testis, a significant amount (95\%) of this immunoreactivity does not co-elute with the authentic peptide following chromatography (Kasson et al. 1985). Also unlike OT, there is little evidence that testicular AVP secretion is regulated by hormonal or spermatogenic factors (Ivell et al. 1992). However, this study suggests that even though the intratesticular concentrations of authentic AVP may be an order of magnitude less than those of OT they may still be sufficient to produce physiologically significant effects on tubule contractility.

$\mathrm{V}_{1 \mathrm{a}}$ receptors have been identified on both rat Leydig cells (Bathgate \& Sernia 1994) and myoid cells (Howl et al. 1995). Our findings that both $V_{1 a}$ antagonists, used at doses related to their $A_{2}$ values, inhibited the AVPstimulated responses and that a selective OTA had little effect on AVP-stimulated contractility suggest that AVP is producing its biological effects via $\mathrm{V}_{1 \mathrm{a}}$ receptors. In addition, although high concentrations of the OTA

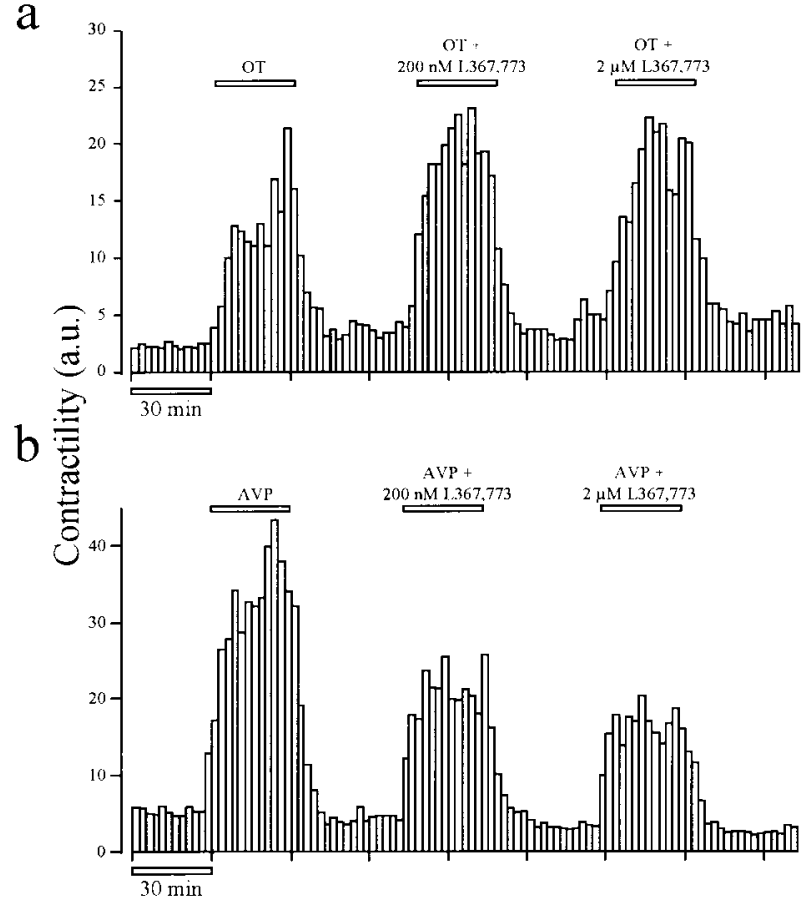

Figure 8 Representative contractility recordings of seminiferous tubules from adult rats showing the effects of the OT antagonist L367,773 (200 nM and $2 \mu \mathrm{M})$ on (a) OT- $(20 \mathrm{nM})$ and (b) AVP$(0 \cdot 2 \mathrm{nM})$ induced increases in seminiferous tubule contractility. Each bar represents the mean contractility of the tubule over a $2 \cdot 5$-min period.

L367,773 and the OT agonist TGOT reduced AVPstimulated contractility, these responses would be expected when their affinity for the $\mathrm{V}_{1 \mathrm{a}}$ receptor is considered (Elands et al. 1988, Evans et al. 1993). Thus, our data confirm the presence of biologically active $\mathrm{V}_{1 \mathrm{a}}$ receptors in the rat testis.

The characterisation of the OT response is less clear. If OT was acting via a classical uterotonic OT receptor, then the response should be mimicked by the specific agonist, TGOT, and inhibited by both peptide and non-peptide OT receptor antagonists. However, whilst the oxytocinstimulated increase in contractility was reduced by the specific OTA desGly- $\mathrm{NH}_{2}, \mathrm{~d}\left(\mathrm{CH}_{2}\right)_{5}\left[\mathrm{~d}-\mathrm{Tyr}^{2}, \mathrm{Thr}^{4}\right]-\mathrm{OVT}$, the non-peptide antagonist L367,773 had no inhibitory effect. Perhaps more surprisingly the specific agonist TGOT did not affect either basal or OT-stimulated contractility. One explanation for these findings is that OT may not act via its own receptor but via the known $\mathrm{V}_{1 \text { a }}$ receptors within the testis (Bathgate \& Sernia 1994, Howl et al. 1995). However, the fact that the OT-stimulated response is affected by the selective OTA desGly$\mathrm{NH}_{2}, \mathrm{~d}\left(\mathrm{CH}_{2}\right)_{5}\left[\mathrm{~d}-\mathrm{Tyr}^{2}, \mathrm{Thr}^{4}\right]-\mathrm{OVT}$ but not by the linear AVPA or the non-peptide antagonist (at doses which reduce the AVP response) would argue against this. Thus, it appears that the effects of OT on tubule contractility do 


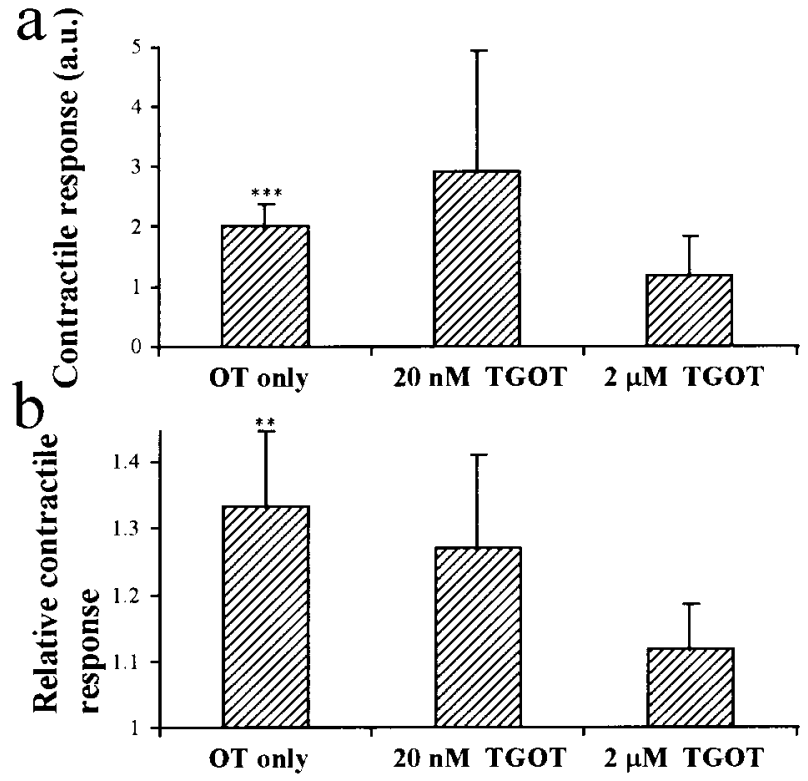

Figure 9 The effects of TGOT on OT- (2 nM) induced increases in seminiferous tubule contractility. Responses are represented as (a) differences in contractility and (b) relative contractility compared with the control period. Data are expressed as means \pm S.E.M. (OT alone, $n=15$; OT+20 nM TGOT, $n=5$ and OT+2 $\mu$ M TGOT, $n=6$ ). ${ }^{* *} P<0 \cdot 01,{ }^{* *} P<0 \cdot 001$ vs linearly interpolated control.

not conform to the pharmacology of the classical OT/AVP receptors (Barberis \& Tribollet 1996). However, by the use of pharmacological studies, it has become clear that, at least in the uterus, more than one subtype of OT receptor exists (Chen et al. 1994). Whilst the myometrial uterine receptor $\left(\mathrm{OT}_{1 \mathrm{a}}\right)$ is activated by TGOT, the endometrial receptor, responsible for prostaglandin release $\left(\mathrm{OT}_{1 \mathrm{~b}}\right)$, is unaffected by this specific OT agonist (Chen et al. 1994). Also, although some OTAs (e.g. desGly- $\mathrm{NH}_{2}, \mathrm{~d}\left(\mathrm{CH}_{2}\right)_{5}$ $\left[\mathrm{d}-\mathrm{Tyr}^{2}, \mathrm{Thr}^{4}\right]-\mathrm{OVT}$ ) act as full antagonists in both systems, others reduce the uterotonic response, but have no effect on OT-stimulated prostaglandin release (Chen et al. 1994). Whilst these latter findings may reflect a mixed population of receptors within the testis, they may be due to another subtype of receptor. More recently a novel subtype of OT receptor has also been postulated in the rat dorsal vagal complex (Tian \& Ingram 1997). This receptor modulates the hypertensive effects of $\mathrm{OT}$ and is reported to be neither a classical $V_{1 a}$ nor $\mathrm{OT}_{1 \mathrm{a}}$ receptor. It is unaffected by TGOT and, as in the testis, the OTstimulated response is inhibited by an OTA but not by an AVPA. Whilst more detailed characterisation is necessary, our preliminary data suggest that the receptor mediating OT's effects on testicular contractile activity is not a classical $\mathrm{OT}_{1 \mathrm{a}}$ receptor. The presence of novel OT/AVP receptors may represent new gene products or may, alternatively, be due to post-translational modification of the classical receptors. Indeed, differences in the affinities

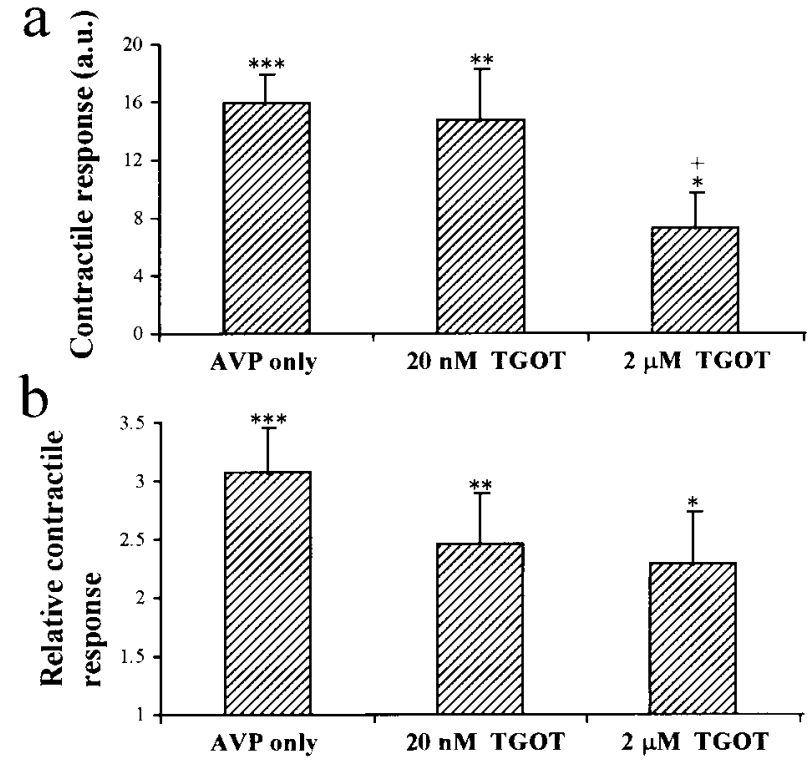

Figure 10 The effects of TGOT on AVP- $(0 \cdot 2 \mathrm{nM})$ induced increases in seminiferous tubule contractility. Responses are represented as (a) differences in contractility and (b) relative contractility compared with the control period. Data are expressed as means \pm S.E.M. $(n=6)$. ${ }^{\star} P<0 \cdot 05,{ }^{*} P<<0 \cdot 01,{ }^{* * *} P<0 \cdot 001$ vs linearly interpolated control. ${ }^{+} P<0.05$ vs AVP alone.

of $\mathrm{V}_{1 \mathrm{a}}$ receptors for AVP between cell types have already been attributed to subtle conformational changes in the receptor depending on the membrane where the receptor is expressed (Howl et al. 1995).

Although our data suggest the presence of a novel type of OT-like receptor, they do not exclude the possibility that the response to OT is mediated indirectly by paracrine factors released by other cells within the seminiferous tubules, such as the Sertoli cells, rather than a direct effect of the peptide on myoid cells. This may also explain the lower potency of OT observed in this system.

In conclusion, whilst evidence exists for a physiological role for OT in the regulation of seminiferous tubule contractility and sperm transport, the relative potencies of the two peptides suggest that AVP may also play an important part in this process. This study also raises the possibility that both a classical $\mathrm{V}_{1 \mathrm{a}}$ receptor and an OT receptor with novel biological characteristics may be present in the rat testis.

\section{Acknowledgements}

The authors would like to thank $\mathrm{M}$ Manning for the kind donation of the antagonists desGly- $\mathrm{NH}_{2}, \mathrm{~d}\left(\mathrm{CH}_{2}\right)_{5}$ $\left[\mathrm{d}-\mathrm{Tyr}^{2}, \mathrm{Thr}^{4}\right]$-OVT, Phaa-d-Tyr(Me)-Phe-Gln-Asn-ArgPro-Arg-Tyr- $\mathrm{NH}_{2}$ and L367,773, and C Serradeil-Le Gal and coworkers, Toulouse, France, for providing the SR 49059 compound. The authors also thank J A Leendertz 
for the production of software and hardware essential for the analysis of tubule contractile activity. G C Harris was supported by an MRC studentship.

\section{References}

Adashi EY, Tucker EM \& Hsueh AJW 1984 Direct regulation of rat testicular steroidogenesis by neurohypophysial hormones: divergent effects on androgen and progestin biosynthesis. Journal of Biological Chemistry 259 5440-5446.

Barberis C \& Tribollet E 1996 Vasopressin and oxytocin receptors in the central nervous system. Critical Reviews in Neurobiology $\mathbf{1 0}$ $119-154$.

Bathgate RAD \& Sernia C 1994 Characterization and localization of oxytocin receptors in the rat testis. Journal of Endocrinology 141 343-352.

Chen DL, Chan, WY \& Manning M 1994 Agonist and antagonist specificities of decidual prostaglandin-releasing oxytocin receptors and myometrial uterotonic oxytocin receptors in pregnant rats. Journal of Reproduction and Fertility 102 337-343.

Elands J, Barberis C \& Jard S $1988\left[{ }^{3} \mathrm{H}\right]-\left[\mathrm{Thr}^{4}, \mathrm{Gly}^{7}\right] \mathrm{OT}$ : a highly selective ligand for central and peripheral OT receptors. American Physiology Society 254 E31-E38.

Evans BE, Lundell GF, Gilbert KF, Bock MG, Kenneth ER, Carroll LA, Williams PD, Pawluczyk JM, Leighton JL, Young MB, Erb JM, Hobbs DW, Gould NP, DiPardo RM, Hoffman JB, Perlow DS, Whitter WL, Veber DF, Pettibone DJ, Clineschmist BV, Anderson PS \& Freidinger RM 1993 Nanomolar-affinity, non-peptide oxytocin receptor antagonists. Journal of Medicinal Chemistry 36 3993-4005.

Foo N, Carter D, Murphy D \& Ivell R 1991 Vasopressin and oxytocin gene expression in the rat testis. Endocrinology 128 2118-2127.

Frayne J, Townsend D \& Nicholson HD 1996 The effects of oxytocin on spermiation and sperm transport in the pubertal rat. Journal of Reproduction and Fertility 107 299-306.

Gravis CJ 1980 Ultrastructural observations on spermatozoa retained within the seminiferous epithelium after treatment with dibutyryl cyclic AMP. Tissue and Cell 12 309-322.

Guldenaar SEF \& Pickering BT 1985 Immunocytochemical evidence for the presence of oxytocin in rat testis. Cell and Tissue Research $240485-487$.

Harris GC \& Nicholson HD 1995 Stage related differences of rat seminiferous tubule contractility in vitro and their response to oxytocin. Journal of Reproduction and Fertility Abstract Series 1554

Howl J, Rudge SA, Lavis RA, Davies L, Parslow RA, Hughes PJ, Kirk CJ, Mitchell RH \& Wheatley M 1995 Rat testicular myoid cells express vasopressin receptors: receptor structure, signal transduction and developmental regulation. Endocrinology 136 2206-2213.

Ivell R, Hunt N, Hardy M, Nicholson H \& Pickering BT 1992 Vasopressin biosynthesis in rodent Leydig cells. Molecular and Cellular Endocrinology 89 59-66.

Kasson BG, Meidan R \& Hsueh AJW 1985 Identification and characterization of arginine vasopressin-like substances in the rat testis. Journal of Biological Chemistry $2605302-5306$.

Manning M, Miteva K, Pancheva S, Stoev S, Wo NC \& Chan WY 1995 Design and synthesis of highly selective in vitro and in vivo uterine receptor antagonists of oxytocin: comparisons with Atosiban. International Journal of Peptide and Protein Research 46 244-252.

Nicholson HD \& Hardy MP 1992 Luteinizing hormone differentially regulates the secretion of testicular oxytocin and testosterone by purified adult rat Leydig cells in vitro. Endocrinology 130 671-677.

Nicholson HD, Swann RW, Burford GD, Wathes DC, Porter DG \& Pickering BT 1984 Identification of oxytocin and vasopressin in the testis and in adrenal tissue. Regulatory Peptides 8 141-146.
Nicholson HD, Worley RTS, Charlton HM \& Pickering BT 1986 $\mathrm{LH}$ and testosterone cause the development of seminiferous tubule contractile activity and the appearance of testicular oxytocin in hypogonadal mice. Journal of Endocrinology 110 159-167.

Nicholson HD, Worley RTS, Guldenaar SEF \& Pickering BT 1987 Ethane-1,2-dimethanesulphonate reduces testicular oxytocin content and seminiferous tubule movements in the rat. Journal of Endocrinology 112 311-316.

Nicholson HD, Greenfield HM \& Frayne J 1994 The effect of germ cell complement on the presence of oxytocin in the interstitial and seminiferous tubule fluid of the rat testis. Journal of Endocrinology 143 471-478.

Niemi M \& Kormano M 1965 Contractility of the seminiferous tubule of the postnatal rat testis and its response to oxytocin. Annales Medicinae Experimentalis et Biologiae Fenniae 43 40-42.

Parvinen M \& Ruokonen A 1982 Endogenous steroids in the rat seminiferous tubules. Comparison of the stages of the epithelial cycle isolated by transillumination-assisted microdissection. Journal of Andrology 3 211-220.

Phillips PA, Abrahams JM, Kelly JM, Mooser V, Trinder D \& Hohnston CI 1989 Localization of vasopressin binding sites in rat tissues using specific $\mathrm{V}_{1}$ and $\mathrm{V}_{2}$ selective ligands. Endocrinology 126 1478-1484.

Pickering BT, Birkett SD, Guldenaar SD, Nicholson HD, Worley RTS \& Yavachev L 1989 Oxytocin in the testis: what, where, and why? Annals of the New York Academy of Sciences $\mathbf{5 6 4}$ 198-209.

Pickering BT, Ayad VJ, Birkett SD, Gilbert CL, Guldenaar SEF, Nicholson HD, Worley RTS \& Wathes DC 1990

Neurohypophysial peptides in the gonads: are they real and do they have a function? Reproduction, Fertility and Development 2 245-262.

Serradeil-Le Gal C, Wagnon J, Garcia C, Lacour C, Guiraudou P, Christophe B, Villanova G, Nisato D, Maffrand JP, Le Fur G, Guillon G, Cantau B, Barberis C, Trueba M, Ala Y \& Jard S 1993 Biochemical and pharmacological properties of SR 49059, a new, potent, nonpeptide antagonist of rat and human vasopressin $V_{1 a}$ receptors. Journal of Clinical Investigation 92 224-231.

Schmidt A, Audigier S, Barberis C, Jard S, Manning M, Kolodziejczyk AS \& Sawyer WH 1991 A radioiodinated linear vasopressin antagonist: a ligand with high affinity and specificity for $\mathrm{V}_{1 \mathrm{a}}$ receptors. Federation of European Biochemical Societies 282 77-81.

Tian PS \& Ingram CD 1997 Evidence for independent hypertensive effects of oxytocin and vasopressin in the rat dorsal vagal complex. Neuroscience Research 27 285-288.

Voglmayr JK 1975 Output of spermatozoa and fluid by the testis of the ram and its response to oxytocin. Journal of Reproduction and Fertility 43 119-122.

Worley RTS \& Leendertz JA 1988 A videomicrographic lowfrequency movement analyser (VLMA) and perifusion chamber for recording and analysis of the physical behaviour of seminiferous tubules and other contractile tissues in vitro. Journal of Microscopy 151 61-69.

Worley RTS, Nicholson HD \& Pickering BT 1984 Testicular oxytocin: an initiator of seminiferous tubule movement? In Recent Progress in Cellular Endocrinology of the Testis, Colloques de l'INSERM vol 123, pp 205-212. Eds JJM Saez, MG Forest, A Dazord \& J Bertrand. Paris: INSERM.

Worley RTS, Appleton MAC, Lyburn ID, Challis JR \& Pickering BT 1988 Concentration-dependent stimulation of seminiferous tubule contractility by oxytocin and its modification by peptide analogues. Regulation of Testicular Function, 10th Annual Testis Workshop, Poster 29.

Received 7 May 1996

Revised manuscript received 19 May 1997

Accepted 25 July 1997 